\title{
Trafficking Routes and Links to Terrorism in South Eastern Europe: The Case of Romania
}

\author{
Lucia Ovidia Vreja*
}

\section{Introduction}

In the twenty-first century, it has become clear that terrorism is the greatest threat to global security, and the one that receives the majority of national and international defense efforts and resources. However, organized crime, in all of its manifestations, cannot be overlooked when dealing with terrorism-related issues. Although a lack of hard evidence makes it difficult to establish an undeniable connection between terrorism and organized crime, all official documents concerning "terrorism-related" activities also include organized crime activities. At a minimum, this signifies that terrorism is, at least indirectly, linked with organized crime - the latter being a very important source of financing for the former. Some officials even assert that terrorism cannot be dissociated from the financing secured by organized crime activities, including drug trafficking, illegal migration, or proliferation of weapons of mass destruction. ${ }^{1}$ Yet the difficult task at hand is to identify an indisputable nexus between terrorist and organized criminal groups - if indeed there is one. ${ }^{2}$

A high level of organized criminal activity undoubtedly characterizes the region of South Eastern Europe. Moreover, a terrorist threat is also present, given the fact that the region has been cited as "chosen as an area of retreat and recovery" for terrorist networks. This status is compounded by the presence of strong Arab communities in almost all of the countries in the region, including "supporters or members of terrorist organizations such as Kongra Gel, Hamas, Hezbollah, the Muslim Brotherhood, Al Qaeda, etc."3

As far as terrorism is concerned, Romanian officials are discussing

* Dr. Lucia Ovidia Vreja is a Research Fellow at the Institute for Political Studies of Defense and Military History at the Romanian Ministry of Defense.

1 Dr. Gheorghe Fulga, former Director of the Romanian External Intelligence Service, "Globalization of Asymmetric Threats Requires Intensifying Cooperation in the Field of Intelligence" (in Romanian), IMPERI 2:4 (2005): 203-10; available at http://www.sie.ro/ Amenintari/amenintari1.html.

2 Even the SECI Regional Center has a task force whose goal is to identify a possible nexus between terrorism and organized crime groups, specifically dealing with trafficking in drugs, human beings, small arms and light weapons (SALW), and weapons of mass destruction (WMD). Thus, they indirectly admit that such criminal activities could be a source of financial resources for terrorist organizations. SECI Annual Report 2005 (Bucharest: Regional Centre for Combating Transborder Crime, 2006); available at www.secicenter.org/events/19/ Anti-Terrorism-Task-Force-Meeting.

3 Dr. Gheorghe Fulga, former Director of Romanian External Intelligence Service, "Romania and the New Threats to Security in South Eastern Europe" (in Romanian), La Lettre Diplomatique 67 (2004); available at www.sie.ro/Amenintari/amenintari3.html. 
vulnerabilities and risks coming from activities developed by members or sympathizers - residing in Romania — of groupings with terrorist ties or records, or activities developed by citizens of states or regions marked by conflict evolutions; the temporary presence in Romania of some persons suspected of membership in terrorist groupings; activities that feed terrorism, mainly associated with transborder organized criminality, etc. ${ }^{4}$

Drug trafficking, organized immigration crime - such as human trafficking and smuggling ${ }^{5}$ - and, to a lesser extent, arms trafficking are the most salient aspects of the phenomenon of organized crime as it relates to terrorism, and all are prominent in South Eastern Europe. Moreover, the routes of drug, arms, and human trafficking overlap due to the "reorientation" of traffickers - in which former traffickers in a certain commodity (for example, arms) become involved in drug or human trafficking. They do this due to the greater demand for such commodities in the market, or because of the larger profits that are available with minimal investment, or "because of the emerging trend of combining several traditional crime areas (cross-commodity smuggling) ${ }^{, 6}$ in order to increase profit.

Regarding the possible nexus between organized crime and terrorism, some assert that drug trafficking, being extremely profitable, is "also linked to international terrorist organizations that need money to finance their activities." Furthermore, "by forging advantageous relationships with drug traffickers or becoming actively involved in the drug trade themselves, terrorist groups such as Hezbollah or Al Qaeda use money from drug sales to further their political agendas.",

At the same time, illegal migration facilitated by human smuggling is an important source of money for organized criminal and terrorist networks, as the migrants have the potential to "become sources of political and financial support for the terrorist organizations." It is even asserted that terrorist networks, along with criminal organizations, are in control of the illegal movement of people across borders, and are working to develop methods to forge documents and control modes of transportation. ${ }^{9}$

Arms trafficking is an equally important part of the link between organized crime and terrorism. This illegal trade not only represents a source of money for terrorist or-

4 Report on the Activity of Romanian Intelligence Service in 2004 (in Romanian); available at www.sri.ro/pdfuri/2-2-2006-Rap_2004.pdf.

5 According to the Serious Organised Crime Agency in the U.K., organized immigration crime covers both the organized facilitation of immigrants ("people smuggling") and the trafficking of people for criminal exploitation, ("human trafficking"). See SOCA Annual Plan-2006/ 2007 (London: Serious Organised Crime Agency, 2006); available at www.soca.gov.uk.

62005 EU Organised Crime Report (Brussels: Council of the European Union, 17 November 2005), document no. 13788/05.

7 The National Youth Anti-Drug Media Campaign, Drugs and Terror: Just the Facts. The Links Between the Drug Trade, Drug Traffickers and Terrorists; available at www.drugstory.net/pdfs/DandT_Fact_Sheet.pdf.

9 Ibid. 
ganizations, but also a trade-off item, as terrorists need arms to achieve their objectives.

Although some experts believe that "alliances between criminal groups and terrorist groups are unusual," organized crime - terrorist organizations whose "tactics increasingly overlap" and progressively rely on revenues obtained through trafficking in drugs, humans, and arms. ${ }^{11}$ South Eastern Europe is a region where such a "hybrid" could become manifest, both because of its troubled history and its current problems, mainly evident in the economic and political arenas, as well as the high level of corruption in state institutions and agencies such as the police, customs, and the judiciary.

In the context of this analysis, one should mention that the "Balkan routes" remain some of the main paths that are used by traffickers and smugglers to enter Western European countries. Romania is primarily a transit country for drugs, migrants, and arms smuggling, and is also an origin country for human trafficking, especially for sexual exploitation. The so-called "northern Balkan route" includes Bucharest, a nexus point for trafficking of all kinds.

\section{Drug Trafficking}

Within Romanian territory, drug trafficking is an activity usually operated by networks of Turkish, Syrian, Iranian, Moldovan, and other Commonwealth of Independent States (CIS) citizens with connections to people in Romania and other Western countries along the trafficking route (including Austria, Germany, and Hungary). ${ }^{12}$

Drug trafficking - mainly in heroin from Afghanistan - is still considered one of the prime criminal activities in the region, and the Balkan routes continue to be the primary way of introducing drugs into the European Union (EU). ${ }^{13}$ Romania represents the main section of the northern Balkan route of drug trafficking to Western Europe. This route starts in Turkey and ends in Western Europe, and relies on several modes of transportation. ${ }^{14}$ In practice, the Turkish mafia controls the northern Balkan route, and the Albanian mafia controls the southern Balkan route; the two criminal groups share a profitable collaboration. For example, ethnic Albanian organized crime groups are "the direct distributors of an estimated 40 percent of heroin in Western European mar-

10 Pat O'Malley and Steven Hutchinson, "Actual and Potential Links Between Terrorism and Criminality," Canadian Centre for Intelligence and Security Studies, Trends in Terrorism ITAC (2006); available at www.csis-scrs.gc.ca/en/itac/itacdocs/2006-5.asp.

11 United Nations, "UN Warns about Nexus Between Drugs, Crime and Terrorism" (30 September 2004), SOC/CP/311; available at http://www.un.org/News/Press/docs/2004/ soccp311.doc.htm.

12 Report on the Activity of the Romanian Intelligence Service in 2004, op cit.

13 Europol, Drugs 2006; available at www.europol.eu.int/publications/SeriousCrimeOverviews/ 2005/drugs2005.pdf.

14 Pierre-Arnaud Chouvy, Michel Koutouzis, and Alain Labrousse, Ministerial Conference on the Drug Routes from Central Asia to Europe, Paris, 21-22 May 2003. 
kets," 15 while the rest of the heroin is brought into the Western markets by Turkish criminal groups. Kosovo Albanians are increasingly present in the Hungarian market as coordinators of shipments of synthetic drugs and heroin purchased mainly from Turkish wholesale traders, using Hungary "to establish heroin storage facilities, just as they do in Bulgaria and Romania."16

The most common variant of this route starts in Turkey, crosses Bulgaria, enters Romania at the Ruse-Giurgiu customs control point, goes through Bucharest, continues to the west through the sub-Carpathian area, and enters Hungary at Arad. It then crosses through Budapest, enters Slovakia at Rajka, and after crossing the Slovakian territory, enters the Czech Republic in the southwest, and continues to Germany and to other Western European countries. Once in Hungary, drugs that are passing along this route can be transported directly to Austria. Another variant of the northern Balkan route includes a maritime sector. It begins in Turkey - typically in Istanbul or Samsun, a Turkish harbor on the Black Sea - and enters Romania at the harbor at Constanta. From here, drugs are transported by car to Bucharest and continue to the west along the same routes described above.

Another route used by Kurdish traffickers extends from Turkey to Athens, then north to Bulgaria at the Kapitan Andreevo customs checkpoint and on to Sofia, finally reaching Bucharest. From Bucharest, the drugs are transported to Budapest and then on to the Czech Republic and Germany. ${ }^{17}$ Occasionally, a variant of the second Balkan route is used. This variant starts in Bucharest, crosses eastern Romania, and enters the Republic of Moldova or Ukraine. From here, the route splits into two different paths to the final destination of Germany: one stretches through Poland to Germany, while the other travels through Slovakia and Czech Republic. At times, drugs can also be transported from Romania to Serbia - which is a main segment of the southern Balkan route - and from Belgrade to Budapest, overlapping with the northern Balkan route.

Drugs also enter into Romania through its international airports, mainly by hashishtrafficking networks based in Africa (Nigeria and Uganda) or cocaine-trafficking networks based in South America (Colombia and Venezuela). Once in Romania, primarily in Bucharest, the traffickers use one of the variants of the northern Balkan route discussed above on their way to Western Europe (see Figure 1).

\section{Illegal Migration and Human Trafficking}

Due to Romania's location at the crossroads of Northern, Eastern, and Western Europe, as well as its 2007 integration into the EU and its prospective 2010 inclusion into the Schengen space, the country occupies a key position along the Balkan route of

15 Glenn E. Curtis (Project Manager), Nations Hospitable to Organized Crime and Terrorism (Washington, D.C.: Federal Research Division, Library of Congress, October 2003), 33; available at www.loc.gov/rr/frd/pdf-files/Nats_Hospitable.pdf.

162004 European Union Organized Crime Report (Luxembourg: Office for Official Publications of the European Communities, December 2004).

17 Radu Tudor, "Terrorism in Romania (I)-Drugs Mafia Finances Terrorist Organization in Romania," Ziua (in Romanian) (11 February 2002). 


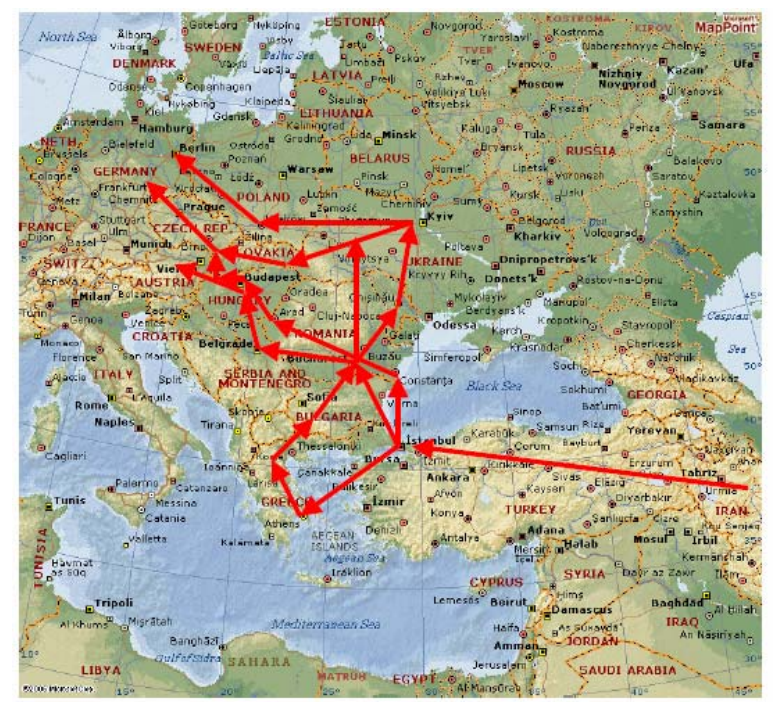

Figure 1: Drug trafficking routes from Turkey to Western Europe

illegal migration. Illegal migration and trafficking in human beings represent extremely serious risk factors for South Eastern Europe, as these activities tend to be even more profitable than drug trafficking. The illegal migration routes crossing through Romania usually originate in Asia (Pakistan, Bangladesh, Afghanistan, Iran, and Iraq), Turkey, and the Commonwealth of Independent States (CIS). Human trafficking often involves Romanian and Moldovan citizens as guides, transporters, and organizers. ${ }^{18}$

According to border police reports, Romania has six main regions with high migration activity. These regions include four entry points and two exit points, on the Hungarian and Serbian borders. The Serbian exit point is also used, in certain cases, as an entry point. The international airports are also used both as entry and exit points. (See Figure 2 below for an illustration of the main routes through Romania.)

The Romanian regions with high migration activity are: ${ }^{19}$

- Eastern Romania, on the border with the Republic of Moldova. This border is mainly crossed by African and Asian migrants, especially those from Somalia, India, Iraq, Pakistan, Sierra Leone, Sudan, Afghanistan, and elsewhere. They use Russian, Ukrainian, and Moldovan guides, and once entering Romania, they either apply for political asylum or try to exit the country at the Hungarian or Serbian borders. Officials assert that, since 2000 (once Romania's measures for

18 Report on the Activity of the Romanian Intelligence Service in 2004, op cit.

19 Marian Chiriac and Monica Robotin, The Strangers Next to Us-2006 (in Romanian) (Bucharest: Centre for Ethno-Cultural Diversity, 2006). 


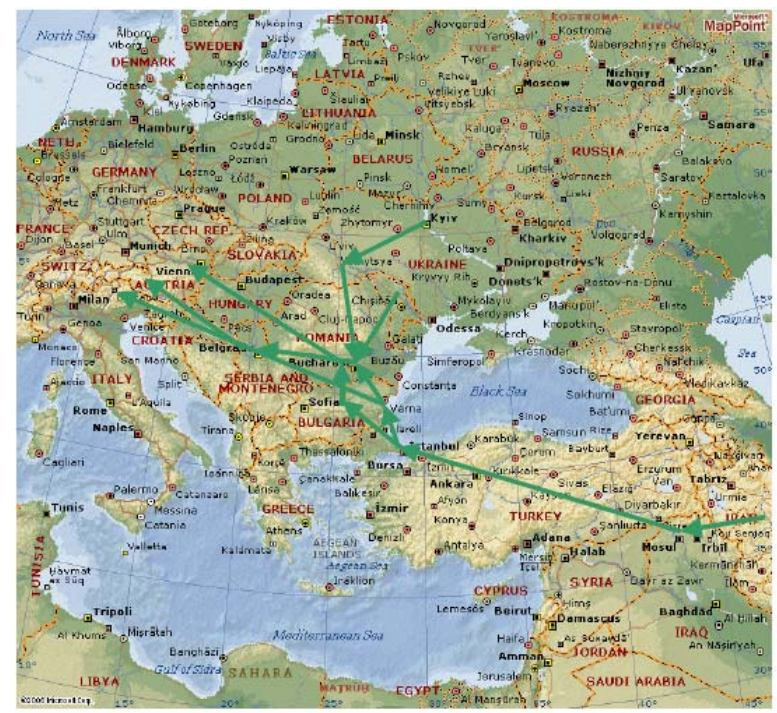

Figure 2: Illegal migration routes in South Eastern Europe

European integration were expedited), the illegal entrance to Romania by this route has significantly decreased.

- Southern Romania, at the border with Bulgaria. Iraqi, Afghan, Pakistani, and Kurdish nationals are especially likely to enter Romania using this route. Since 2000 , officials have observed an increase of the number of people trying and succeeding to enter the country via this route.

- Northern Romania, at the border with Ukraine. African and Asian citizens are the primary entrants via this route.

- International airports. Most often, citizens from Turkey (ethnic Kurds), China, Iran, and Iraq use forged Schengen visas and passports to obtain entry via Romania's international airports.

- Western Romania, at the border with Hungary. This region is most often used as an exit point. Illegal migrants, especially Africans or Asians, use this route to reach Western Europe.

- Southwestern Romania, at the border with Serbia. This area is primarily used for forced human trafficking, especially of girls from former Soviet republics and from Romania intended for sexual slavery. 
Covert illegal migration is also a frequent occurrence in Romania. ${ }^{20}$ For example, Turkish citizens, after legally entering the country using valid Turkish passports, then use forged Greek, Swedish, and Bulgarian passports or Italian residence permits in order to exit the country on the western frontier. Another frequent pattern is that Moldovan citizens, once they have entered the country legally, try to exit the country with the assistance of Romanian citizens, using forged Romanian, Belgian, Lithuanian, Polish, Slovak, or Bulgarian passports or Italian, German, Greek, or Spanish residence permits. Citizens of Singapore also try to enter Romania by using stolen Japanese and Singaporean passports, and Serb nationals try to enter Romania using forged Slovenian passports.

At the same time, asylum seekers in Romania have often been discovered trying to illegally cross the borders with Serbia and Hungary-especially asylum seekers from Somalia, Bangladesh, Nigeria, Liberia, and India. According to official data, the primary states whose citizens have illegally approached Romanian borders (at both entrance and exit points) are: India, Iraq, Pakistan, Turkey, Georgia, the Republic of Moldova, Liberia, and Nigeria. ${ }^{21}$

It is worth mentioning that the International Organization for Migration (IOM) has a database of the most common countries of origin for human trafficking worldwide, which ranks five southeastern European countries at the top of the list: Moldova, Romania, Ukraine, Belarus, and Bulgaria. The four primary points where IOM has offered assistance to victims of trafficking are the Former Yugoslav Republic of Macedonia (FYROM), Bosnia-Herzegovina, Kosovo, and Albania. ${ }^{22}$ According to the U.S. Department of State, more than 100,000 persons are trafficked from the former Soviet Union and 75,000 from Eastern Europe each year. ${ }^{23}$ It is estimated that Balkan criminal networks are responsible for the trafficking of 200,000 to 700,000 persons worldwide, mainly for forced prostitution. ${ }^{24}$

Romania is a country of origin for human trafficking, primarily due to the large number of poor people there. Because of its geographic position, it is also a transit country for trafficking victims from Moldova, Ukraine, and Asian countries to Bosnia and Herzegovina, Serbia and Montenegro, FYROM, Kosovo, Albania, and Western Europe. $^{25}$

20 The Analysis of the Human Trafficking Phenomenon Made by Romanian Border Police (in Romanian) (Bucharest: General Inspectorate of Border Police, 20 June 2006); available at www.politiadefrontiera.ro.

21 Ibid.

22 IOM, World Migration 2005, Section 3, International Migration Data and Statistics (Geneva: International Organization for Migration, 2006), 418; available at www.iom.int/jahia/ webdav/site/myjahiasite/shared/shared/mainsite/published_docs/books/wmr_sec03.pdf.

23 State of World Population 2006 - A Passage to Hope: Women and International Migration (New York: United Nations Population Fund, 2006), 45.

24 A Secure Europe in a Better World - European Security Strategy (Brussels: European Union, 12 December 2003); available at http://ue.eu.int/uedocs/cmsUpload/78367.pdf.

25 Trafficking in Persons Report (Washington, D.C.: U.S. State Department, June 2002); available at www.state.gov/g/tip/rls/tiprpt/2002. 
Until 2002, the Balkans, especially Serbia and Montenegro as well as Albania, represented the main destination points to which women and girls from Romania and Moldova were trafficked. From here, they were then transferred to other Balkan countries or to Western Europe (most often Belgium, Luxembourg, Italy, or France). Since 2003, however, the main destinations of Romanian, Moldovan, and even Ukrainian victims have shifted to include Spain, Italy, France, the Netherlands, Austria, Greece, or Cyprus. $^{26}$

Moldovan, Ukrainian, Russian, or even Asian victims are trafficked through Romania using the eastern route; Romanian officials have reported a decrease in the traffic at the eastern border. ${ }^{27}$ According to recent findings, several alternative trafficking routes have emerged in South Eastern Europe in addition to the traditional ones, making it difficult for officials to detect new transit points. ${ }^{28}$

Romania remains the primary transit center for victims of trafficking, with several main routes starting from or passing through Romania. One route goes directly to Serbia and from there to other Balkan countries. The other route goes through southern Romania and then through Bulgaria and FYROM towards Greece and Turkey. ${ }^{29}$ To reach Western Europe, the most commonly used routes seem to be Romania-HungaryAustria-Germany or, alternatively, Romania-Hungary-Czech Republic-Western Europe (see Figure 3 below). At times, Slovakia, Serbia, Croatia, and Slovenia may also be transit countries. ${ }^{30}$ In the other direction, according to the IOM, Turkey has become one of the "largest markets" for women trafficked from Moldova, Ukraine, and other former Soviet states, "with crime syndicates there pocketing up to $\$ 3.6$ billion in 2005.",31

Logically, human trafficking routes often overlap with illegal migration routes. The main regional trafficking routes include: ${ }^{32}$

- Ukraine-Moldova-Romania-Serbia-other Balkan countries

- Ukraine-Moldova-Romania-Bulgaria-Turkey-Greece

- Ukraine-Moldova-Romania-Hungary-other EU countries.

26 Trafficking in Persons Report (Washington, D.C.: U.S. State Department, June 2003, June 2004, and June 2005); available at www.state.gov/g/tip/rls/tiprpt/.

27 The Analysis of the Human Trafficking Phenomenon Made by Romanian Border Police, op cit.

28 Ladan Rahmani, "Invisible Routes. Changing Patterns and Trends in Trafficking Routes in the Balkans," Migration (June 2005): 22-24; available at www.iom.int/jahia/webdav/site/ myjahiasite/shared/shared/mainsite/published_docs/periodicals_and_newsletters/june_2005. pdf. Ibid, 23.

30 Trafficking in Women from Romania into Germany-Comprehensive Report March 2005 (Turin: United Nations Interregional Crime and Justice Research Institute, March 2005).

31 State of World Population 2006-A Passage to Hope, 45.

32 Operation Mirage Evaluation Report (Bucharest: SECI Center, 21 January 2003); available at www.secicenter.org/p172/Evaluation_Report_2003. 


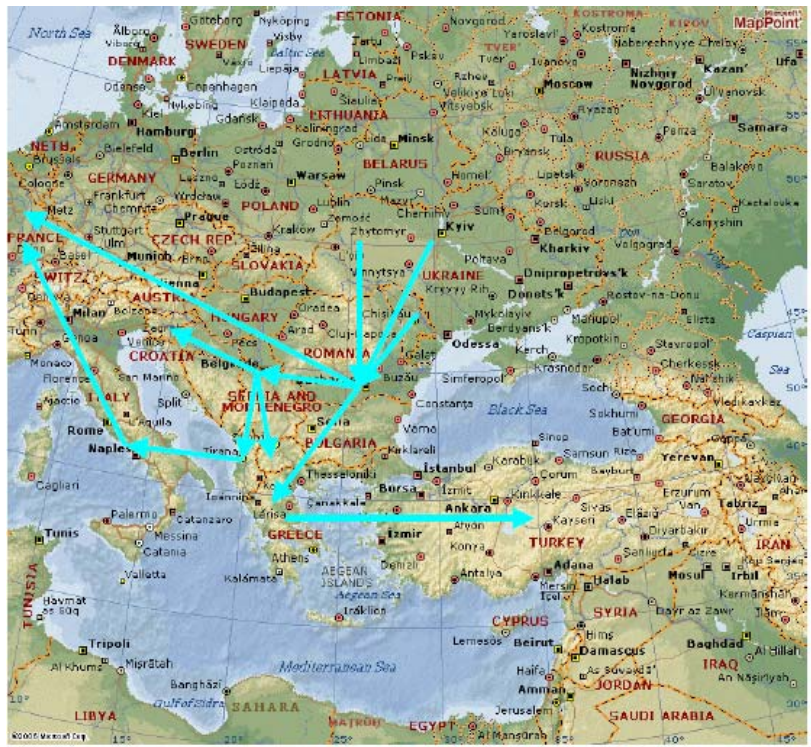

Figure 3: Human beings trafficking routes in South Eastern Europe

Trafficking in human beings understandably overlaps with "both regular and irregular migration"-where it involves violence, confinement, coercion, deception, and exploitation - and also intersects with smuggling. Currently, the distinction between these forms of organized migration crimes is somewhat "fuzzy.",33

\section{Arms Trafficking}

In Romania, the risks generated through the traffic in arms, weapons of mass destruction, and dangerous substances have considerably decreased within the past few years. Criminal groups from Russia, Moldova, the former Yugoslavia, Turkey, Greece, Cyprus, Syria, and Lebanon are involved in the smuggling and illegal traffic of small arms and ammunition. ${ }^{34}$ Such activities mainly occur at Romania's borders with the Republic of Moldova and Ukraine, ${ }^{35}$ and likely at the border with Bulgaria as well.

Nevertheless, Romania is the focus of criminal entities from states in Asia, the Middle East, and Central and North Africa that are trying to acquire weapons of mass destruction (WMD) and other dangerous substances. ${ }^{36}$ Moreover, Romania might still be a transit country for arms exports to countries under embargo or to EU countries.

33 State of World Population 2006-A Passage to Hope, 44.

${ }^{34}$ Report on the Activity of the Romanian Intelligence Service in 2004, op cit.

35 Ibid.

36 Ibid. 


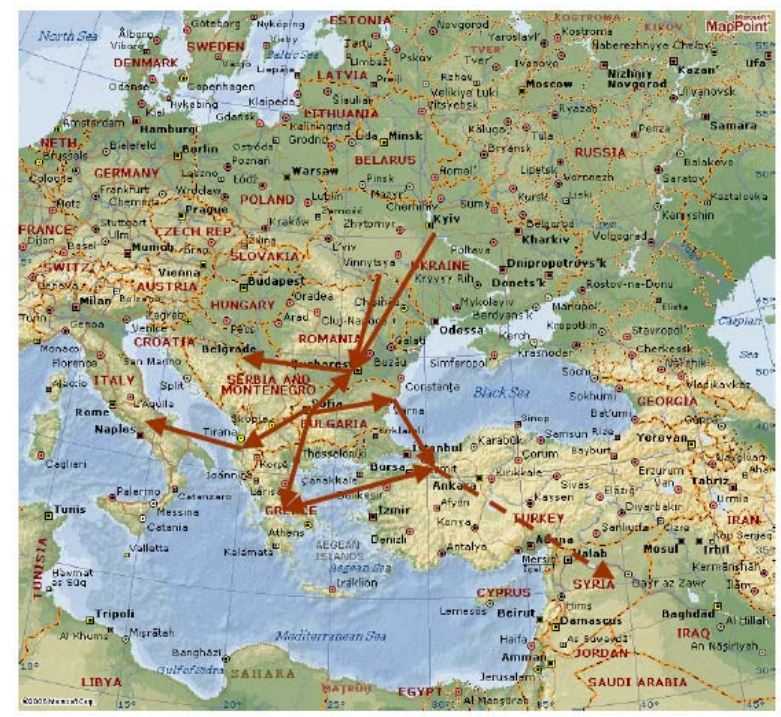

Figure 4: Arms trafficking routes in South Eastern Europe

The Balkan region is instrumental "concerning firearms trafficked into the EU." Although the numbers of arms trafficking cases reported in Romania are not significant enough to indicate high-level activity in this field, crime groups in Bulgaria are being monitored as "heavily involved in illicit firearms trafficking" destined for markets in Greece, the Netherlands, Italy, Spain, Great Britain, and Turkey. ${ }^{37}$ Accordingly, the main route for trafficking firearms to Western Europe is either from Turkey to Serbia or from Bulgaria to the FYROM and Albania, and then onward to other destinations. ${ }^{38}$

Although the region was characterized by a high level of illegal arms trafficking until 2000, particularly because of the wars in the former Yugoslavia during the 1990s, recent reports indicate a significant decrease in this kind of criminal activity. This decrease is either due to a lower demand for arms or to the reorientation of criminal groups toward more profit-generating businesses, such as trafficking in drugs or human beings. The Bucharest-based Regional Center for Combating Transborder Crime reported the existence of several illegal weapons depots on the territories of neighboring SECI member countries. These weapons were discovered in an operation that led to the arrest of seventeen people and the seizure of a significant amount of weapons, ammunition, and even anti-tank missile launchers and detonation devices planted in mobile phones. ${ }^{39}$

2005 EU Organised Crime Report.

Ibid.

39 SECI Annual Report 2005 (Bucharest: Regional Centre for Combating Transborder Crime, 2006); available at www.secicenter.org/p222/Activity_Report_on_2005. 


\section{The Nexus Between Trafficking and Terrorism}

South Eastern Europe is a region with an undeniable link between transborder trafficking in drugs, arms, and human beings. Over time, evidence has shown that, in South Eastern Europe, trafficking of illegal immigrants "seems to be organized by the same groups who were previously engaged in the smuggling of weapons and drugs," or that "often they [traffickers] combine two businesses - trafficking of illegal immigrants and smuggling of drugs." ${ }^{40}$ Despite proven connections between weapons, drugs, and human trafficking, claims for a similar link between these forms of trafficking and terrorism are controversial. However, such a link can be determined by reading between the lines and connecting the dots between the various forms of criminal activity that plague the region.

Drug trafficking is very often related to human smuggling and trafficking as a method of increasing efficiency and profit. ${ }^{41}$ Usually, the leaders of different networks develop haphazard partnerships regarding the recruitment and organization of their agents, as well as the use of existing routes and transport across borders. Similarly, networks dealing in illegal immigration - a form of crime that has gained new ground in the last few years - often take advantage of preexisting drug trafficking routes or networks, moving both "commodities" in parallel or even together. ${ }^{42}$ For example, in a joint five-year police operation called "Harem," eighty people were arrested in five European countries (Italy, Germany, Ukraine, Serbia, and Croatia) for drug, arms, and human trafficking violations. ${ }^{43}$ Albanians were arrested in the western coastal cities of Durraz, Vlore, and Kavaja, as well as in the capital of Tirana. They were found to have links with the Italian organized crime group known as Ndrangheta, which operates in the southern region of Calabria. According to the police, Ndrangheta allowed the forced prostitution of girls from Eastern Europe in exchange for arms and drugs imported from Albania. ${ }^{44}$

Ethnic Albanian criminal groups, while preserving their hierarchical and homogeneous structure, are increasingly cooperating with other organized crime groups in Eastern Europe. Their joint efforts include drug trafficking and human trafficking, mainly for sexual exploitation, as well as various kinds of property crimes. ${ }^{45}$ Such partnerships have also allegedly been established between organized crime networks and

40 Marko Hajdinjak, Smuggling in Southeast Europe-The Yugoslav Wars and the Development of Regional Criminal Networks in the Balkans (Sofia: Center for the Study of Democracy, 2002), 50.

41 Interpol and Drug Trafficking, Fact Sheet COM/FS/2006-03/DCO-01; available at www.interpol.int/Public/icpo/FactSheets/DCO01.pdf. See also Europol, Drugs 2006, op cit.

42 Europol, Organised Illegal Immigration into the European Union (2005); available at www.europol.eu.int/publications/SeriousCrimeOverviews/2005/overview_illegal_immigratio n.pdf.

43 Xinhua General News Service, 14 December 2005, cited in Organized Crime News; available at www.iasoc.net/news.htm.

44 Ibid.

452005 EU Organised Crime Report. 
terrorist organizations; these two groups provide each other support, or rely on the same infrastructure to reach their goals. Moreover, nearly every terrorist group is raising some money from organized crime activities, especially (but not limited to) the drug trade and other economic crime, such as money laundering. Organized crime activities are a very convenient and profitable source of financing for terrorist organizations "because of the major cash benefits derived from relatively minimal time and investment." 46

According to official state institutions, organized crime - especially drug trafficking - represents the most important source of financial support for terrorist groups, providing up to an estimated 30 to 40 percent of their funds. ${ }^{47}$ This assertion is logical, given the fact that international terrorism is no longer exclusively state-sponsored, and terrorist organizations have been forced "to become much more self-sufficient" regarding their financial resources. ${ }^{48}$

Ethnic Albanian organized criminals constitute one of the largest criminal groups in Europe, closely cooperating with international criminal organizations and perhaps also linked with terrorist groups, including Al Qaeda. Reports from the U.S. government indicate that "Osama bin Laden was channeling, in 2001, profits from the sale of narcotics arriving in Western Europe via the Balkan route to local governments and political parties, with the goal of gaining influence in Albania or Macedonia or both." Furthermore, in 2002, "Al Qaeda had acted as a middleman in the movement of heroin from warehouses in Afghanistan via Chechen mafia conduits and into the Balkan narcotics pipeline, taking a percentage of the drug profits for this service." 49

Although terrorist networks in South Eastern Europe are difficult to uncover, and the dependence between these groupings and organized crime networks is hard to prove, the evidence that exists must not be ignored. More and more data indicates that Al Qaeda has a presence in the western Balkans and that Albania, Bosnia, and Kosovo may be becoming "European hotbeds of Iranian-backed Islamic terrorism, and $\mathrm{Al}$ Qaeda in particular." 50

46 Interpol and Drug Trafficking, Fact Sheet COM/FS/2006-03/DCO-01.

47 Romanian Intelligence Service, Combating the Financing of Terrorist Organizations (in Romanian) (Bucharest: Romanian Intelligence Service); available at www.sri.ro/pdfuri/1-62003-combaterea finantarii organizatiilor teroriste.pdf.

48 David E. Kaplan, "Paying for Terror: How jihadist groups are using organized-crime tactics - and profits - to finance attacks on targets around the globe," U.S. News \& World Report (5 December 2005); available at www.usnews.com/usnews/news/articles/051205/ 5terror.htm. Other Extremist Groups (Washington, D.C.: Federal Research Division, Library of Congress, May 2002); available at www.loc.gov/rr/frd/pdf-files/NarcsFundedTerrs_Extrems.pdf. Security Environment, eds. Russell D. Howard and Reid L. Sawyer (Guilford, CT: McGrawHill, 2004), 133. See also: "Europe May Face a New Wave of Domestic Terrorism," Richard Bennett Media-AFI Research (7 April 2002); available at http://www.milnet.com/afi/AFIResearch-0415.htm. 
New evidence about the terrorist presence in the Balkans shows that the region "could serve as a haven for Al Qaeda linked terrorist groups." In June 2005, Abdelmajid Bouchar, a 22-year-old Moroccan suspected of being involved in the March 2004 train bombings in Madrid, was caught at the Belgrade railway station in a train that arrived from the northern town of Subotica, located on the border with Hungary. ${ }^{51}$ Even some "skeptical" experts, who currently do not consider the Balkans or South Eastern Europe to be "a key region harboring or funding terrorists," do note "that the region may play a secondary role in terrorist plans, as a transit point for terrorists, as well as for rest and recuperation., ${ }^{, 52}$

Authorities in South Eastern European countries, with the exception of the western Balkans, assert that there is no terrorist threat in the region. Bulgarian officials, for example, have stated that "there are no problems concerning Islam or terrorism in Bulgaria," 53 despite the fact that some outside authorities believe that Bulgaria may be a terrorist transit point for operatives en route to Western Europe. Similarly, Hungarian representatives assert that there is no Al Qaeda presence in Hungary, the country is not a direct target for terrorist organizations or "groups connected to them," and "Muslims living in Hungary are scarce in number and are basically not inclined to extremism, with no ties to terrorist organizations." Yet, these same officials also admit that "members of extremist groups or organizations described as terrorist may infiltrate into the country and may form groups rendering logistic aid" due to legal and illegal migration. $^{54}$

Nevertheless, external sources have issued conflicting reports. For example, according to the U.S. Central Intelligence Agency (CIA), about a dozen Arabs with Bulgarian citizenship have been identified as members of the most active terrorist groups in Iraq ${ }^{55}$ which has been denied by Bulgarian intelligence. EU officials also admit that in Hungary, certain Middle Eastern groups also take part in the distribution of heroin. ${ }^{56}$ This is the case in Romania as well, where Turkish, Syrian, and Iranian citizens are known to be involved in drug trafficking.

Until recently, Romanian authorities adopted the same position as their counterparts in Bulgaria and Turkey, asserting that there have been no threats of a possible terrorist attack against a national target in Romania. According to the former director of the Romanian Intelligence Service, there is no clear evidence indicating the presence of

51 "Concerns of Al-Qaeda Link in Balkans Renewed. Madrid Attack Suspect Arrested in 'Springboard for Europe-bound Terrorism'," Associated Press, 29 August 2005.

52 Steven Woehrel, Islamic Terrorism and the Balkans (Washington, D.C.: Congressional Research Service, 26 July 2005); available at www.fas.org/sgp/crs/terror/RL33012.pdf.

53 "Jihad in Bulgaria," Jihad Watch (13 January 2004); available at www.jihadwatch.org/ archives/000625.php.

54 National Security Office-Yearbook 2005 (Budapest); available at www.nbh.hu/english/ evk2005-eng/05-0041.htm.

55 "Arabs of Bulgarian Citizenship on Iraq's Terrorist Lists" (2 December 2004); available at www.jihadwatch.org/archives/004141.php.

562004 European Union Organized Crime Report. 
Al Qaeda or Islamic Jihad members in Romania. Yet other sources have gathered information on Muslim citizens living in Romania who might conduct financial activities supporting both Al Qaeda and Islamic Jihad, as well as on the significant involvement of Romania-based cadres of non-Islamic terrorist organizations - such as the Kurdistan Workers' Party (PKK) or the Grey Wolves - in drug trafficking along routes that reach Germany and the Netherlands. ${ }^{57}$

The trafficking of illegal migrants is also a very important and highly profitable form of organized crime in the region, and is an area where the link between organized crime and terrorism is more evident. For example, EU member states are increasingly concerned about the significant numbers of illegal immigrants reaching Western Europe from the Balkan region, the Russian Federation, China, Iraq, the sub-Saharan African countries, India, Afghanistan, and Pakistan. These illegal migrants are using the Balkans, Russia, and other parts of Eastern Europe as transit points to enter the EU. ${ }^{58}$

The Balkans, according to local officials and experts, if not a "safe haven" for terrorist bases, is "at least a major transit route for the terrorists as well as organized criminals, including human and drug traffickers, the two often going hand-in-hand." Porous borders in the region, "such as the one between Romania and Serbia, are wide open to gangs that smuggle people, heroin and goods," allowing the establishment of "hidden alliances" between terrorist groups and "organized crime gangs that control heavily used smuggling routes in the Balkans," thus "making it easier for terrorists to infiltrate Western Europe." ${ }^{\prime 60}$ Moreover, some experts even believe that "in some cases the money earned by human traffickers is used to support terrorist activities in Europe." 61

Aside from the use of illegal migrant smuggling as a source of financing terrorist organizations and activities - which is debatable - it is now common sense to assert that routes of human smuggling are used by potential terrorists themselves to reach Western Europe through the South Eastern European countries. Though some analysts argue that there is insufficient evidence to indicate a symbiotic relationship between organized crime networks and terrorist groups, it is hard to believe that terrorist organizations would not make use of such a profitable, low-cost business. Even if there were no formally established relationship, terrorist and organized crime networks could still easily find a way to achieve mutually beneficial cooperation. Terrorists could be smuggled to a particular destination by organized crime networks in exchange for a certain sum of money, since criminal gangs do not care about the political, social, or

57 Radu Tudor, "Romanian Anti-terrorist Brigade Extends the Cooperation in the Fight against Terrorism," Jane's Intelligence Review (January 2002).

58

Europol, Organised Illegal Immigration into the European Union.

59 "Concerns of Al-Qaeda Link in Balkans Renewed," Associated Press, op cit.

60 Gregory Katz, "Terrorists said to be getting aid in the Balkans: Crime gangs that control the smuggling routes are making their infiltration easier," Houston Chronicle (27 December 2005).

61 Ibid. 
ethnic orientation of the migrants they traffic. The primary motivation of criminal gangs is economic profit; this makes their networks available to terrorists who can pay for their services.

Once in a South Eastern European country, terrorists posing as migrants can either attempt to apply for political asylum or, most often, illegally travel further west. In Romania, for example, a large number of asylum seekers come from Muslim countries $^{62}$ such as Iraq, Afghanistan, Pakistan, Iran, Iran, or Syria, where terrorist organizations are very active. Moreover, among the tens of thousands of persons transiting through Romania from countries such as Iraq, Pakistan, or Afghanistan, there are some who have relations with terrorist networks, including Al Qaeda. Even more important, some of these persons manage to obtain Romanian citizenship. ${ }^{63}$

In this context, it is worth considering the allegation that the northwestern Iraqi province of Anbar has become the new headquarters of Al Qaeda, from where people and resources can be directed to mount new attacks in Western Europe. Furthermore, the former chief of the Iraqi wing of Al Qaeda, the Jordanian Abu Musab al-Zarqawi, established a "working relationship" with "Middle Eastern criminal smuggling rings linked to European and African Mafias" in order to facilitate the movement of operatives, logistical plans, and funds out of Iraq and into new fronts. ${ }^{64}$ Moreover, according to Europol, organized crime groups involved in illegal migration "can also be found within the ethnic communities" already present in the destination state, a finding that may also apply in case of Romania. ${ }^{65}$

Even since the communist era Romania has been home to a sizeable community of Arabs with connections to high-level officials and involvement in large and profitable businesses, usually in the fields of real estate, tourism (hotels or travel agencies), transport, and import-export. According to official data, 13,774 companies have 35,624 Arab associates residing in Romania. Unsurprisingly, most Arab businesses and businesspersons in this country are from Iraq (5,227 companies, with 11,010 people); Syria (3,051 companies, with 10,041 people); Lebanon (2,328 companies, with 7,163 people); Jordan (1,456 companies, with 3,920 people); and Egypt (1,006 companies, with 1,992 people). ${ }^{66}$ However, these numbers are almost certainly higher, given the fact that many Arabs already have Romanian citizenship. In addition, several Arabs were involved in media scandals and even penal trials related to trafficking in alcohol

62 For example, according to the Romanian National Office for Refugees, from 1991 to 31 July 2005, the figures of asylum seekers in Romania are as follows: 3089 Iraqi, 1522 Afghani, 980 Pakistani, 799 Iranians, and 189 Syrians. See Chiriac and Robotin, The Strangers Next to Us-2006, 27.

63 Radu Timofte, former Director of Romanian Intelligence Service, cited by Mediafax News Agency, 29 March 2004.

64 "Zarqawi Dilutes Iraq Network, Leads New Al Qaeda Offensive in Europe and Middle East," Debka-Net-Weekly (23 July 2005); available at www.debka.com/article.php?aid=1059.

65 Europol, Organized Illegal Immigration into the European Union.

66 Andi Laslau, "Arabs in Romania, A Complete Radiography" (in Romanian), Evenimentul Zilei (Bucharest) (27 April 2005). 
and cigarettes or other economic crimes. Some of them are even suspected of financing or having links to terrorist organizations in their countries of origin. Although they might not be directly involved in smuggling activities, some of these suspects could easily be involved in smuggling or trafficking-related activities. They can provide material support in the form of forged documents, financing, accommodation, and transportation given the fact that they run hotels, travel agencies, or transport companies. For example, it is known that there are organized groups that focus exclusively on document forgery. Usually, secondary documents for trafficking or smuggling victims are "also procured and forged with the help of persons in the transit or destination countries," perpetrated by travel agencies or transport companies. ${ }^{67}$

Several Islamic organizations are also present in Romania, some of them reported or suspected of having links with extremist terrorist organizations, including Al Qaeda. For example, in October 2005, Israeli authorities arrested two Arab Israelis who had formerly been students in Romania. They were recruited by Hamas while studying in Romania and received terrorist training in Turkey. ${ }^{68}$ The Muslim Brotherhood in Romania also has a significant logistical base that consists of buildings - allegedly used as Islamic community centers, prayer houses, and mosques - present in most important Romanian university towns, all of them very well equipped with communication and information networks, printing presses, and copying machines. ${ }^{69}$ Sponsorship for these buildings is mainly provided by the Islamic and Cultural League in Romania, which coordinates the activity of branches of the Muslim Brotherhood and Hamas in Central and Eastern Europe. Although these groups are not involved, at least visibly, in economic activities in Romania, the U.S. Federal Bureau of Investigation (FBI) reports that, in the United States, the financial operations of Hamas include drug trafficking. These reports also indicate financial links between Hamas and Al Qaeda, despite a lack of any formal affiliation. ${ }^{70}$

Romania is also hosting terrorist groups involved in economic activities, including Hezbollah, whose funding is derived from both legal and illegal commercial activities. Allegedly, the country is used as a refuge and recovery location for Hezbollah members who have taken part in terrorist actions abroad. ${ }^{71}$ The Party of Islamic Liberation (Hizb-ut-Tahrir), which has a presence in Romania's principal university centers, is

${ }^{67}$ Trafficking in Women from Romania into Germany-Comprehensive Report March 2005 (Turin: United Nations Interregional Crime and Justice Research Institute, March 2005).

68 Andi Topala and Andrei R. Dobrogea, "Two Former Arab Students in Romania have Supported the Terrorist Organization Hamas for 10 Years" (in Romanian), Gardianul (Bucharest) (25 October 2005).

69 Radu Tudor, "Terrorism in Romania (II)-Terrorist Organizations Muslim Brothers and Hamas Have Tens of Members in our Country" (in Romanian), Ziua (12 February 2002). Michael Rubin, "Popular Notions Laid Bare," review of Mathew Levitt, Hamas: Politics, Charity, and Terrorism in the Service of Jihad (New Haven, CT: Yale University Press, 2006), New York Sun (23 May 2006); available at www.meforum.org/article/936.

71 Radu Tudor, "Terrorism in Romania (III)-Hezbollah-Commercial and Propaganda Activities in Romanian University Centers" (in Romanian), Ziua (13 February 2002). 
rumored to have members involved in legal and illegal commercial activities that finance the organization. ${ }^{72}$ Moreover, reports indicate that members of the Hezbollah militia are "engaged in [the] heroin and hashish trade, cigarette smuggling, counterfeiting, extortion, [and] fraud.",73

There is also a significant Turkish community, which either resides in or transits through Romania, and some of its members are involved in organized crime activities. In Romania, almost every case of drug trafficking involves at least one Turkish citizen. The money obtained from the drug trade is also used to finance the activities of some terrorist organizations. For example, an important portion of international drug trafficking networks are under the control of the non-Islamic terrorist organization PKK, and its profits are directed toward support for the organization's logistical bases or for arms purchase. ${ }^{74}$ For the Romanian branch of the PKK, drugs and human trafficking are among the main sources of financing; covert institutions, such as inter-ethnic leagues, cultural associations, and companies (mainly trade and transport companies) also provide income. ${ }^{75}$

Turkish citizens also coordinate important illegal smuggling networks, making use of Romanians or foreigners as guides. They usually recruit co-nationals, or use Africans and Asians who want to go to Western Europe. They have created a strong operational and support base in border regions, composed of couriers, taxi drivers, hosts, and guides, most of whom are driven by economic necessity. ${ }^{76}$ Often, the people smuggled from Turkey, especially Kurds, use Romanian territory as a place of refuge; they are usually suspected of participating in either trafficking activities or terrorism-related activities in Turkey. ${ }^{77}$ Equally important is the fact that Turkey is a well-known host of Islamist terrorist training camps.

From 2000 to 2001 alone, Romania expelled seventy people suspected of having links to terrorist organizations, most of them members or supporters of the PKK or the Grey Wolves. ${ }^{78}$ Even members of Islamist terrorist organizations or suspected supporters of Al Qaeda have been expelled from Romania. On 1 July 2006, Yemeni citizen Mohtar Hashedi, a member of the Muslim Brotherhood, a group that is known to support terrorist efforts, was expelled from Romania. He was allegedly in charge of recruiting new members and organizing the activity of the organization in Constanta

Ibid.

73 Kaplan, "Paying for Terror."

74 Radu Tudor, "Terrorism in Romania (I)-Drugs Mafia Finances Terrorist Organization in Romania."

75 Radu Tudor, "Terrorism in Romania (IV)-PKK has in Romania over 1500 Members and Sympathizers" (in Romanian), Ziua (14 February 2002).

76 Radu Tudor, "Terrorism in Romania (I)."

77 Ibid.

78 Radu Tudor, "Terrorism in Romania (VII)-The List of Terrorists Expelled from Romania" (in Romanian), Ziua (16 February 2002). 
county. ${ }^{79}$ The branch of the Muslim Brotherhood active in Romania is considered to support Al Qaeda. Seven Arab citizens were arrested on 4 February 2005, and four more on 27 February 2006, all of them members of the Muslim Brotherhood. ${ }^{80}$

In this context, the distinction between terrorism and organized crime is blurry. Organized crime activities, such as drug and human trafficking, can easily be used to support terrorism. Moreover, there appears to be an overlap between smuggling routes used by terrorist groups and organized crime syndicates. ${ }^{81}$ More and more evidence suggests that "terrorists worldwide are transforming their operating cells into criminal gangs," as "terrorist gangs in Europe ... traffic in drugs and illegal aliens."

Although some analysts argue that a nexus between organized crime and terrorism is unlikely, because "organized criminal groups tend to be nationalistic, territorial, and reluctant to risk the attention from authorities that accompanies cooperation with terrorist groups," ${ }^{\prime 3}$ the reality shows something different. Currently, organized criminal groups are no longer nationalistic or territorial; rather, they are inclined to seek any cooperation that will extend and ease their "business" and help them to find new markets. Both trafficking networks and terrorist organizations now have more flexible (rather than hierarchical and rigid) structures. Instead, these organizations employ more network-like structures with a very specialized division of tasks. Furthermore, since organized crime and terrorist networks are both in need of similar things, they may be able to use the same infrastructure. In fact, "both crime syndicates and terrorist groups thrive in the same subterranean world of black markets and laundered money, relying on shifting networks and secret cells to accomplish their objectives." 84

Terrorist groups exploit the "gray areas" where states are weak and corrupt and the rule of law is nonexistent. ${ }^{85}$ Given the weakness of the central governments of several states in the region, South Eastern Europe could be an area where terrorist networks and criminal networks overlap. ${ }^{86}$ Terrorist and criminal organizations, though they have different long-term objectives, are both characterized by a convergence of interests: they need weak states, permeable borders, political and economic instability, corruptible officials, and inefficient state institutions in order to operate effectively. This convergence of interests is powerful enough to create an arrangement of convenience, if not an outright alliance, leading to a joint use of resources, methods, and infrastructure. Even though the lack of pertinent official data makes it difficult to establish unde-

79 Carmen Mocanu, "Romanian Intelligence Service Catches Terrorists Regularly" (in Romanian), Ziua (3 July 2006).

80 Mirabela Amarandei, "Arabs Suspected of Terrorism, Arrested in Iasi" (in Romanian), Romania Libera (1 March 2006).

81 Kaplan, "Paying for Terror."

82 Ibid.

83 O'Malley and Hutchinson, "Actual and Potential Links Between Terrorism and Criminality."

84 Kaplan, "Paying for Terror."

85 Douglas Farah, "Draining Terror's Financial Swamps," The Middle East Forum (11 October 2004); available at www.meforum.org/article/648.

86 Ibid. 


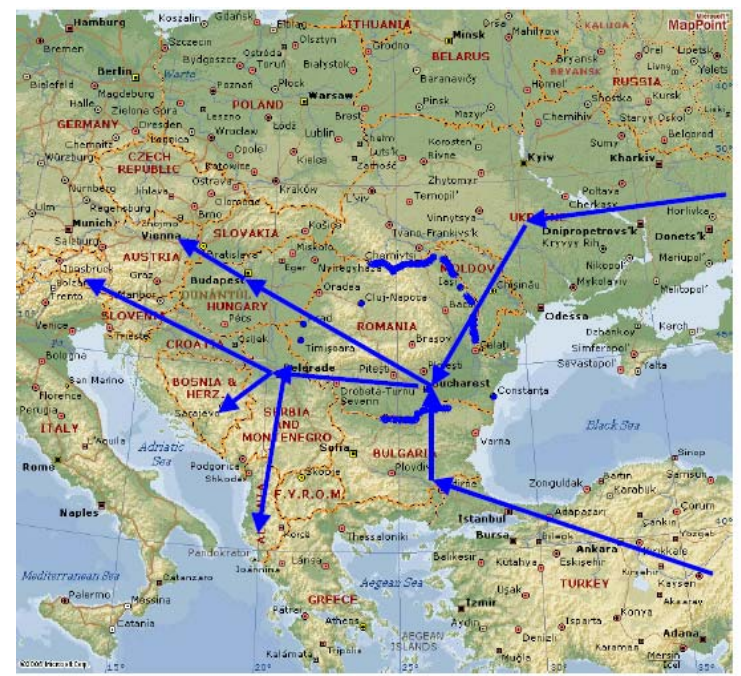

Figure 5: Possible terrorist routes in South Eastern Europe; vulnerable borders; and Muslim presence in Romania ${ }^{89}$

niable and definitive alliances or links between terrorists and criminals, simple, common-sense logic leads to this conclusion.

All things considered, South Eastern Europe is at the very least used as a transit region for terrorists targeting Western Europe (see Figure 5). Austria is a new base for "Islamic extremists and terrorist re-organization," as the Austrian authorities have recently identified thirteen Islamist organizations "suspected of having links with the Salafist Jihad" already installed in Austria. ${ }^{87}$

As the chief of the Serbian border police has emphasized, the region "is the crossroads of the trade in illegal immigrants, weapons, and drugs, and no one can say terrorists cannot pass." 88 This warning should lead researchers to adopt a more concerned and attentive attitude when dealing with the nexus between organized crime and terrorism in the region.

87 Liese Prokop, Austrian Minister of Internal Affairs, cited in Mirela Barba, "Austria-A Base of Re-organization for Terrorists," Curentul (Bucharest) (29 July 2005).

88 Cited in Gregory Katz, "Terrorists said to be getting aid in the Balkans."

89 The vulnerable sections of Romania's borders are indicated by dotted lines. Sizeable Muslim communities are indicated by darker round dots. 


\section{THE QUARTERLY JOURNAL}

\section{Bibliography}

2004 European Union Organized Crime Report. Luxembourg: Office for Official Publications of the European Communities, 2004.

2005 EU Organised Crime Report. Brussels: Council of the European Union, 2005.

A Secure Europe in a Better World - European Security Strategy. Brussels: European Union, 2003.

Affairs, Liese Prokop Aus. "Austria-A Base of Re-organization for Terrorists." Curentul(2005).

Amarandei, Mirabela. "Arabs Suspected of Terrorism, Arrested in Iasi." Romania Libera(2006).

Annual Report 2005. Bucharest: SECI, Regional Centre for Combating Transborder Crime, 2006.

Arabs of Bulgarian Citizenship on Iraq's Terrorist Lists., 2004.

Chiriac, Marian, and Monica Robotin. The Strangers Next to Us-2006. Bucharest: Centre for Ethno-Cultural Diversity, 2006.

Chouvy, Pierre-Arnaud, Michel Koutouzis, and Alain Labrousse. "Ministerial Conference on the Drug Routes from Central Asia to Europe." In Ministerial Conference on the Drug Routes from Central Asia to Europe. Paris , 2003.

Combating the Financing of Terrorist Organizations. Bucharest: Romanian Intelligence Service, 2003.

Curtis, Glenn E.. Nations Hospitable to Organized Crime and Terrorism. Federal Research Division, Library of Congress, 2003.

Europe May Face a New Wave of Domestic Terrorism. Richard Bennett Media-AFI Research, 2002.

Farah, Douglas. Draining Terror's Financial Swamps. The Middle East Forum, 2004.

Fulga, former Director o. "Globalization of Asymmetric Threats Requires Intensifying Cooperation in the Field of Intelligence." IMPERI 2, no. 4 (2005): 203-10.

Fulga, former Director o. "Romania and the New Threats to Security in South Eastern Europe." La Lettre Diplomatique 67 (2004).

Hajdinjak, Marko. Smuggling in Southeast Europe-The Yugoslav Wars and the Development of Regional Criminal Networks in the Balkans. Sofia: Center for the Study of Democracy, 2002. 
Hudson, Rex A.. A Global Overview of Narcotics-funded Terrorist and Other Extremist Groups. Washington: D.C.: Federal Research Division, Library of Congress, 2003.

International Migration Data and Statistics. In World Migration 2005, 418. Geneva: International Organization for Migration, 2006.

Interpol and Drug Trafficking., 2006.

Jenkins, Brian Michael. "Countering Al Qaeda." In Defeating Terrorism: Shaping the New Security Environment. Guilford: CT: McGraw-Hill, 2004.

Jihad in Bulgaria. Jihad Watch, 2004.

Kaplan, David E.. "Paying for Terror: How jihadist groups are using organized-crime tactics - and profits - to finance attacks on targets around the globe." (2005).

Katz, Gregory. "Terrorists said to be getting aid in the Balkans: Crime gangs that control the smuggling routes are making their infiltration easier." Houston Chronicle (2005).

Laslau, Andi. "Arabs in Romania, A Complete Radiography." Evenimentul Zilei (2005).

Levitt, Mathew. Hamas: Politics, Charity, and Terrorism in the Service of Jihad. New Haven: CT: Yale University Press, 2006.

Mocanu, Carmen. "Romanian Intelligence Service Catches Terrorists Regularly." Ziua(2006).

O’Malley, Pat, and Steven Hutchinson. Actual and Potential Links Between Terrorism and Criminality In Trends in Terrorism. ITAC, Canadian Centre for Intelligence and Security Studies , 2006.

Operation Mirage Evaluation Report. Bucharest: SECI Center, 2003.

Rahmani, Ladan. "Invisible Routes. Changing Patterns and Trends in Trafficking Routes in the Balkans." Migration (2005).

Report on the Activity of Romanian Intelligence Service in 2004 ., 2004.

SOCA Annual Plan-2006/2007. London: Serious Organised Crime Agency, 2006.

State of World Population 2006 - A Passage to Hope: Women and International Migration. New York: United Nations Population Fund, 2006.

The Analysis of the Human Trafficking Phenomenon Made by Romanian Border Police. Bucharest: General Inspectorate of Border Police, 2006. 


\section{THE QUARTERLY JOURNAL}

Topala, Andi, and Andrei R. Dobrogea. "Two Former Arab Students in Romania have Supported the Terrorist Organization Hamas for 10 Years." Gardianul (2005).

Trafficking in Persons Report 2002. Washington: D.C.: U.S. State Department, 2002.

Trafficking in Persons Report 2003, 2004, 2005. Washington: D.C.: U.S. State Department, 2003.

Trafficking in Women from Romania into Germany-Comprehensive Report March 2005. Turin: United Nations Interregional Crime and Justice Research Institute, 2005.

Trafficking in Women from Romania into Germany-Comprehensive Report March 2005. Turin: United Nations Interregional Crime and Justice Research Institute, 2005.

Tudor, Radu. "Romanian Anti-terrorist Brigade Extends the Cooperation in the Fight against Terrorism." Jane's Intelligence Review (2002).

Tudor, Radu. "Terrorism in Romania (I)-Drugs Mafia Finances Terrorist Organization in Romania." Ziua (in Romanian) (2002).

Tudor, Radu. "Terrorism in Romania (II)-Terrorist Organizations Muslim Brothers and Hamas Have Tens of Members in our Country." Ziua (2002).

UN Warns about Nexus Between Drugs, Crime and Terrorism. United Nations, 2004.

Woehrel, Steven. Islamic Terrorism and the Balkans. Washington, D.C.: Congressional Research Service, 2005.

Zarqawi Dilutes Iraq Network, Leads New Al Qaeda Offensive in Europe and Middle East. Debka-Net-Weekly, 2005. 